\title{
DETERMINATION OF MAINTENANCE PRIORITY INDEX (MPI) FOR COMPONENTS ON RSG-GAS SAFETY SYSTEM
}

\author{
Entin Hartini ${ }^{1}$, Sukmanto Dibyo ${ }^{1}$, Santosa Pujiarta ${ }^{2}$ \\ ${ }^{1)}$ Center for Nuclear Reactor Technology and Safety (PTKRN Batan), ${ }^{2}$ Center For Multipurpose Reactor \\ Kawasan Puspiptek, Tangerang Selatan, 15310 \\ entin@batan.go.id \\ Diterima editor: 1 Mei 2018 \\ Diperbaiki: 5 Juni 2018 \\ Disetujui untuk publikasi: 6 Juni 2018
}

\begin{abstract}
DETERMINATION OF MAINTENANCE PRIORITY INDEX (MPI) FOR COMPONENTS ON RSG-GAS SAFETY SYSTEM. Reliability management is an activity to ensure no failure of all equipment when operated. Reliability management can be optimized to minimize costs or eliminate failures and causes. Critical equipment is the condition of a potentially damaging component affecting the operational reliability of the system. The criticality level of each equipment determines its impact on the operating system and the direction of maintenance improvement. The research was conducted on the main system/component of the operating system and performed at the level of reliability improvement. The purpose of this research is to prioritize the reliability of systems and equipment for safety systems using System \& Equipment Reliability Prioritization (SERP). Determination of component criticality level on reliability management based on category rankings of frequency data and duration of interference with certain criteria as well as system aspects, safety, quality and cost. From the evaluation results it can be concluded that the MPI of the RSG-GAS system/ component for the top 5 if sorted are KBE01 AP-01-02, PA01-02 / CR001, KBE02 AA-01/ AA-02, JE-01 (AP01-02 ) and JNA10 / 20/30 BC001 with MPI values $143,101,95,90$ and 60 .
\end{abstract}

Keywords: Maintenance, priority, index, safety system, RSG-GAS

\section{ABSTRAK}

PENENTUAN MAINTENANCE PRIORITY INDEX (MPI) UNTUK KOMPONEN PADA SISTEM KESELAMATAN RSG-GAS. Manajemen keandalan merupakan suatu kegiatan untuk menjamin tidak terjadinya suatu kegagalan pada seluruh komponen saat dioperasikan. Dengan manajemen keandalan dapat dilakukan optimasi untuk meminimumkan biaya atau menghilangkan kegagalan dan penyebabnya. komponen kritis merupakan kondisi suatu komponen yang berpotensi mengalami kerusakan yang berpengaruh pada keandalan operasional sistem. Tingkat kekritisan dari setiap komponen menentukan dampaknya terhadap sistem operasi dan arah penyempurnaan pemeliharaan. Penelitian dilakukan pada sistem/komponen yang utama dari sistem operasi dan dilakukan pada level peningkatan keandalan. Tujuan dari penelitian ini adalah menentukan indeks prioritas pemeliharaan (MPI) untuk peringkat keandalan sitem/komponen pada system keselamatan menggunakan metode System \& Equipment Reliability Prioritization (SERP). Penentuan tingkat kekritisan komponen pada manajemen keandalan berdasarkan peringkat kategori dari data durasi dan frekuensi gangguan dengan kriteria tertentu serta aspek sistem, keselamatan, kualitas dan biaya. Dari hasil evaluasi dapat disimpulkan bahwa MPI dari sistem/komponen RSG-GAS untuk 5 teratas jika diurutkan adalah: KBE01 AP-01-02, PA01-02 / CR001, KBE02 AA-01 / AA-02, JE-01 (AP01-02) dan JNA10 / 20/30 BC001 dengan nilai MPI berturut turut 143,101, 95, 90 dan 60.

Kata kunci: Pemeliharaan, prioritas, indeks, sistem keselamatan, RSG-GAS

DOI: $10.17146 / t d m .2018 .20 .2 .4283$ 


\section{INTRODUCTION}

The operation process of a reactor is determined by the condition of the system/ component to perform its function. Damage to one unit of the system / component can interfere even cause the cessation of reactor operation. The main problem of system/component of RSG- GAS is aging. In this case the repair process plays a very important role in ensuring the availability of the system/component therefore a good reliability management system is required. The reliability management system has not been performed in RSG-GAS, therefore reliability management is required in order to predict damage to the system/component and can be given proper maintenance on all systems and components so as to support aging management of RSG-GAS[1,2].

Reliability management is an activity to ensure no failure of the system/component at the time of operation, does not decrease the capacity with optimum cost and minimize or eliminate the failure and its cause and do the optimization. Each equipment has a different level of criticality on the reliability of the system. The criticality level of each equipment determines its impact on the operating system and the direction of maintenance improvement. There are several methods commonly used to determine criticality levels, such as Commercial Criticality Analysis (CCA), Reliability Center Maintenance (RCM), Analysis and System \& Equipment Reliability Prioritization (SERP). The SERP is part of the reliability improvement program that must be implemented so that maintenance optimization program can run well. The output of the SERP process is the MPI (maintenance priority index) that serves to focus and prioritize the improvement of an asset. If the criticality of the system/component is known, it can be determined the strategy and priority of the appropriate maintenance work program to improve the reliability of RSG-GAS systems/components. SERP will provide input at the next stage, namely Failure Defense Planning (FDP). FDP is an engineering approach to achieving maximum operational reliability. FDP consists of Failure Mode and Effect Analysis (FMEA) and Root Cause Failure Analysis. Prior to FDP, System \& Equipments Reliability Prioritization (SERP) is required to obtain $10 \%$ critical equipment from assets owned [3, 4].

Maintenance priority index (MPI) is used for an approach that prioritizes reliability with a proposed maintenance strategy consisting of a state index and an interest index, taking into account the critical component conditions in the reliability of the system [5]. Identify Maintenance Significant Items (MSI) is performed through a combination of quantitative analysis with qualitative analysis. Filtering the non MSI portion is performed through the first screening that defines the system boundary, system hierarchy and Risk Analysis (RA) of the risk matrix. Perform failure analysis of Mode and Effects Analysis (FMEA) and perform RA based on risk matrix [6]. Perform adjustment of condition-based maintenance and spare parts planning for a multi component system using Markov Decision Process model by minimizing average cost per unit time average [7]. A mathematical model and numerical algorithm were developed to obtain an optimal maintenance strategy [8]. Application of risk-based and reliability methods for operation and maintenance planning [9]. Selective maintenance optimization model is performed to maximize system reliability under time and cost constraints [10]. Maintenance planning is based on timely conditions for multi-component system [11]. Implementation of missing value handling method for evaluating the system/component maintenance historical data [12]. Perform clustering analysis to Improve reliability and maintenance with self-organizing map neural network [13].

The purpose of this study is to determine the reliability management approach that produces the system and safety that will be prioritized for maintenance (Maintenance Priority Index). Evaluate appropriate treatment methods for defective systems and equipment.

The methodology used in this research is System \& Equipment Reliability Prioritization (SERP) method. The SERP is used to determine the value of Criticality Ranking System (SCR), Operation Criticality Ranking (OCR), Asset Failure Probability Factor (AFPF). The above values are used to determine the maintenance priority index (MPI) with system reliability priority. 


\section{THEORY}

\section{Reactor Cooling System and Related Systems}

The primary system of the reactor comprising the primary cooling system, the secondary cooling system and the decay heat dissipation system is shown in Figure 1. The function of the primary and secondary cooling systems is to ensure the temperature inside the core and reflector within the permitted operating range as long as the reactor operates normally until power thermal design. The decay heat dissipation system is used to remove the decay heat after the reactor is shut down normally and as long as the main power supply (from PLN) is interrupted

As long as the reactor operates at high power, the heat released in the core and around the reflector is taken up by the primary cooling system that flows downward through the core and reflector. The primary cooling system is cooled in a heat exchanger in which heat is transferred to a secondary cooling system circuit and then discharged into the atmosphere through a forced air conditioning cooling tower. The primary cooling system is earthquake resistant designed to withstand Safe Shut-down Earthquake, SSE so system integrity is assured. The core decay heat dissipation after the shut-down reactor can be done with the main cooling system (primary and secondary cooling systems) or pool cooling system.

Primary refrigeration systems are intended to extract mechanical activation and impurity products from the reactor pool water and maintain primary coolant quality at a certain level. It is important to limit the radiation levels in the operating hall and installation rooms and provide clear water in the reactor pool so that it can clearly visually see the inside of the pool. While the purification system and the warm water pool layer provide a purified warm water layer on the surface of the reactor pool with temperatures slightly higher than the temperature of the pond to prevent the rise of active impurities to the pool surface. In addition, the system provides water filling and flushing on neutron beam tubes.

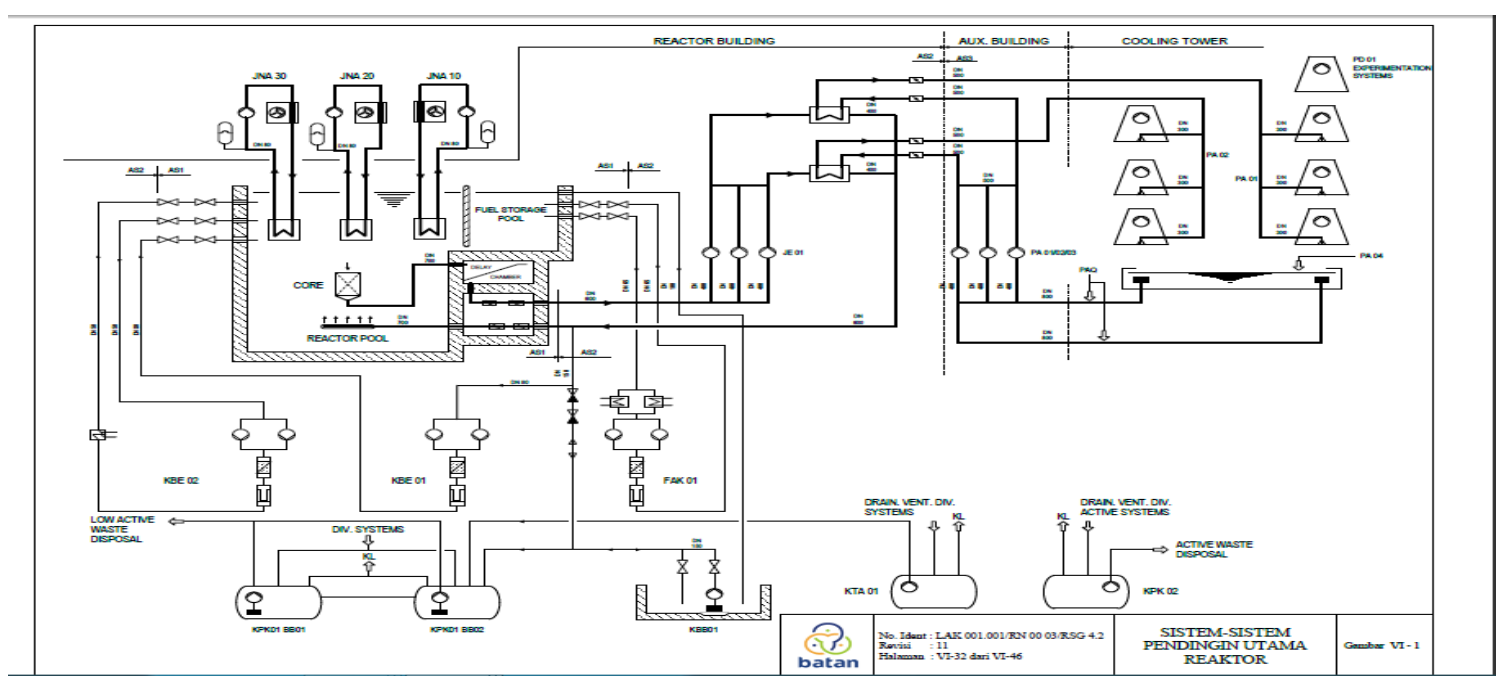

Figure 1. Reactor Main Cooling Systems.

\section{Concept and Purpose of Maintenance in Management}

The reliability of the system/component is the aging of the equipment (system or component) Therefore maintenance management is required especially in the operation and maintenance procedures. Determination of criticality and priority of components is required, thereby reducing disruption as the system/component operates. Maintenance is a concept of all activities necessary to maintain the quality of equipment in order to function properly as before. 
The purpose of maintenance is to extend the useful life of the asset (system/component) to ensure the optimum availability of the equipment, to ensure operational readiness of all equipment required in an emergency at all times and to know the damage as early as possible so that fatal damage can be avoided[1-4].

\section{System Equipment Reliability Priorityzation (SERP)}

SERP (System Equipment Reliability Prioritization) is a method for ranking the reliability of equipment system. The result of the SERP process is the maintenance priority index (MPI) in the form of ranking equipment (system or component) based on certain criteria that determine the criticality level of equipment based on total data and frequency of damage. The result of MPI and equipment mapping is an initial identification process that provides an overview of critical equipment that must be immediately handled and rated reliably [4-6]. The outputs generated by this SERP process are as follows:

1. MPI (maintenance priority index) the final output oh the SERP process that serves to focus and prioritize the improvement of an asset.

2. Criticality Ranking System (SCR)

3. Operation Criticality Ranking (OCR)

4. Asset Failure Probability Factor (AFPF)

\section{System Criticality Ranking (SCR)}

SCR consists of:

1. OC (Operational Cost)

Operational Cost is the average maintenance cost during (2010-2015). In million rupiah from $0-200$ with a value of rank $1-5$.

2. PT (Throughput Process)

Throughput process is a system aspect is the impact of the loss of function or time range of improvement. The rank 1-5 for the repair time range is 0 to greater than 30 days.

3. SF (Safety)

Safety is assessed based on the classification of components in RSG-GAS installation divided into safety class with grade A, B and C, the quality class with rank 1-3. Where tolerances are given 0 to $10 \%$ for equipment /components and seismic classes (not included). $S F=S C+Q C$

$$
S C R=\frac{\left(O C^{2}+P T^{2}+S C^{2}+Q C^{2}\right)^{1 / 2}}{4}
$$

\section{Operational Criticality Ranking}

Operational Criticality Ranking (OCR) is obtained based on the duration of the failure of the asset affecting the system functional failure.

\section{Asset Criticality Ranking}

Asset Criticality Ranking (ACR) is obtained by combining the values of SCR and OCR which will result in a ranking of a device based on criticality. ACR on the system is worth:

$$
A C R=S C R \times O C R
$$




\section{Asset Failure Probability Factor (AFPF)}

The AFPF value is obtained by looking at the reliability level of the equipment with the measured parameters as the frequency of damage from the equipment in the period of 2010-2015.

\section{Ranking System Guidelines}

1. SERP determines the basic system in a unit, where the system is a collection of assets/ equipment

2. The critical system of units is measured by different aspects of the operation of the units (ranking categories) in the system criticality ranking (SCR)

3. Ranking equipment located on each system, based on its criticality to the function of the system to determine operational criticality ranking (OCR) on each item.

4. Operational criticality combined with system criticality of unit operation that is asset criticality ranking (ACR)

5. Determining factor of the failure rate of equipment. Reliability is determined on a numerical scale. This factor of reliability (Asset Failure Probability Factor - AFPF). Combine AFPF with ACR to determine Maintenance Priority Index (MPI).

\section{METHODOLOGY}

The methodology used is to approach the reliability management process that produces the system and safety that will be prioritized on the main system/component of the operating system. The reliability management approach is carried out at the reliability level, namely System and Equipment Reliability Prioritization (SERP) to determine the value of Maintenance Priority Index (MPI) on the system/component of the RSG-GAS. Determination of Maintenance Priority Index needs to identify critical equipment and system ranking guidelines first. Stages performed on research:

1) Collecting secondary data for maintenance data system/components RSG-GAS year 2010 to 2015 (core configuration number 70 to 88 ) for primary cooling system, secondary cooling system and heat dissolution decay system.

2) Identification and verification of data

3) Establish system ranking guidelines based on an assessment of impacts for reliability management on SSC of RSG-GAS. Among them: frequent interference, duration of system/component interference, safety, system, quality and cost aspects.

4) Preparation of tables required for the identification of critical equipments to determine the maintenance priority index (MPI), including Critical ranking system: Operational cost, Throughput and Safety (SCR), Operation Critical Ranking (OCR) and Failure Probability Factor (AFPF)

5) Calculate the total frequency and total damage of all systems/components during 2010-2015

6) Perform MPI calculations and evaluation of results.

Stages of the research methodology are presented in Figure 2. 


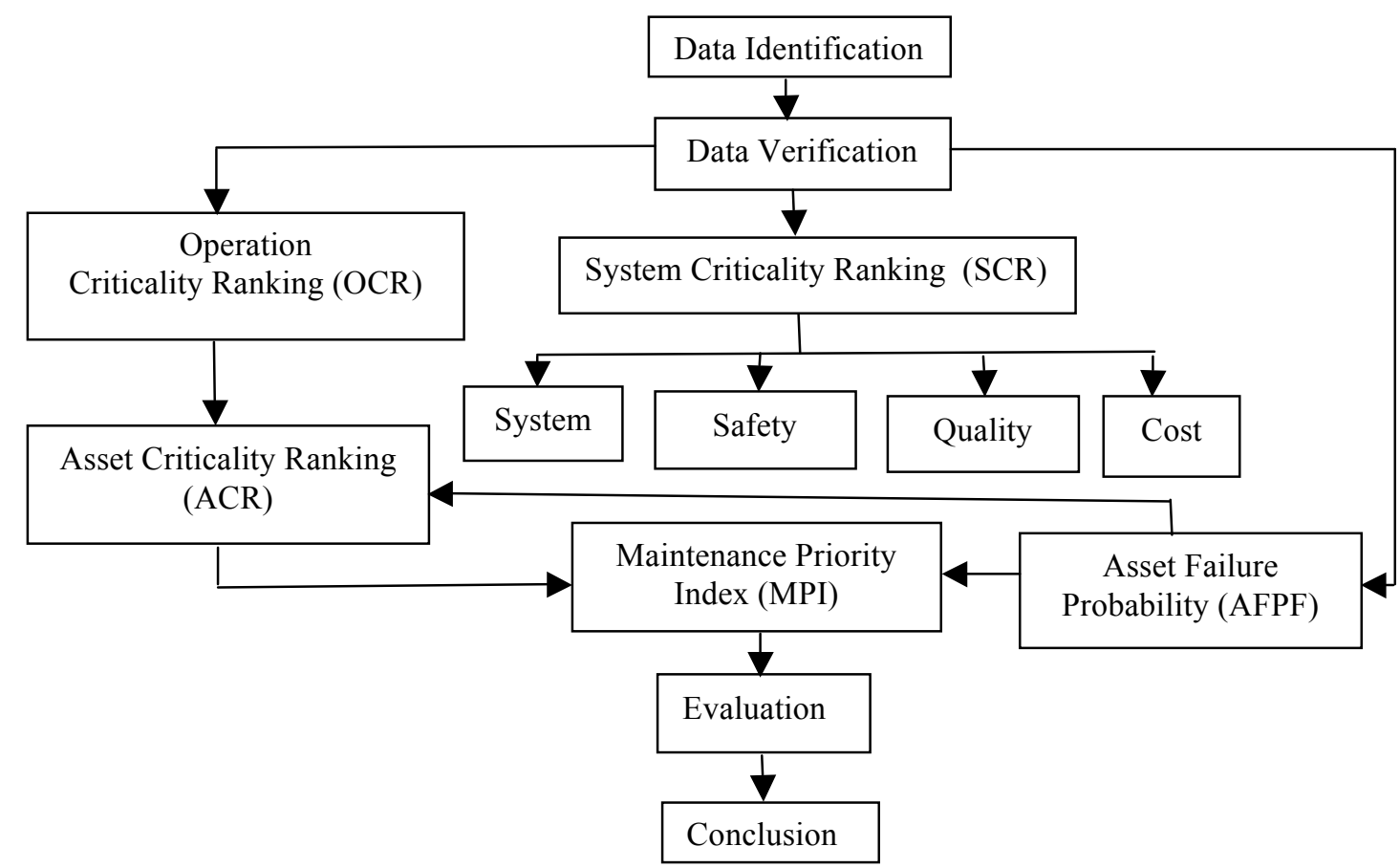

Figure 2. Stages of The Research Methodology

Data used in critical equipment analysis using secondary data from systems /components of maintenance data using core configuration number 70 to 88 (2010-2015). In this study focused on the category of structure system component (SSC) RSG-GAS. Maintenance data can be analyzed for components of primary and secondary cooling systems, purification systems and heat dissolution systems.

\section{RESULTS AND DISCUSSION}

Results of collecting RSG-GAS SSC maintenance data for Cooling System and Related Systems are shown in Table 1

Table 1 Data Duration and Frequency of Interference In Cooling Systems and Related system of SSC RSG-GAS (2010-2015)

\begin{tabular}{|l|l|l|c|c|c|}
\hline Subsystem & \multicolumn{1}{|c|}{ Component } & Code & $\begin{array}{c}\text { Duration } \\
\text { of Repair } \\
\text { (days) }\end{array}$ & $\begin{array}{c}\text { frequency of } \\
\text { interference }\end{array}$ & $\begin{array}{c}\text { percentage of } \\
\text { interference } \\
\text { frequency }(\%)\end{array}$ \\
\hline $\begin{array}{l}\text { Primary } \\
\text { Cooling }\end{array}$ & $-\begin{array}{l}\text { Primary pump } \\
\text { System } \\
\text { Instrumentation of } \\
\text { the primary system } \\
\text { (The ultrasonic } \\
\text { sensor water level } \\
\text { indicator) } \\
\text { Automatic trip } \\
\text { reactor }\end{array}$ & JE-01(AP01-02) & 112 & 9 & 12.7 \\
& JAA01 (CL001) & 18 & 2 & 2.8 \\
\hline
\end{tabular}




\begin{tabular}{|c|c|c|c|c|c|}
\hline $\begin{array}{l}\text { Secondary } \\
\text { Cooling } \\
\text { System }\end{array}$ & $\begin{array}{l}\text { - Backup pump } \\
\text { - Valves in press } \\
\text { pipes and backflow } \\
\text { pipes. } \\
\text { - Suction insulation } \\
\text { valves } \\
\text { - Conductivity gauge } \\
\text { (located inside the } \\
\text { main suction pipe) } \\
\text { - Secondary System } \\
\text { Instrumentation } \\
\text { Flow } \\
\text { - Instrumentation } \\
\text { measurement of } \\
\text { activity } \gamma \\
\text { continuously }\end{array}$ & $\begin{array}{l}\text { PA-03 AP-01 } \\
\text { PA01-02/ AA-14 } \\
\text { and PA01-02/ } \\
\text { AA } 16 \\
\text { PA-01-02-03/AA- } \\
03 \\
\text { PA-01 CQ001 } \\
\text { PA01-02/CF002 } \\
\text { PA01-02/CR001 }\end{array}$ & 41 & $\begin{array}{l}1 \\
1\end{array}$ & 4.2 \\
\hline $\begin{array}{l}\text { Primary } \\
\text { Purification } \\
\text { System }\end{array}$ & $\begin{array}{l}\text { - Primary } \\
\text { purification pump } \\
\text { - Activity monitor } \\
\text { - Isolation valve }\end{array}$ & $\begin{array}{l}\text { KBE01 AP-01-02 } \\
\text { KBE01 CR001 } \\
\text { KBE01 AA-67/ } \\
\text { AA-68 }\end{array}$ & $\begin{array}{l}173 \\
20 \\
25\end{array}$ & $\begin{array}{l}2 \\
5\end{array}$ & $\begin{array}{l}15.5 \\
2.8 \\
7.0\end{array}$ \\
\hline $\begin{array}{l}\text { Purification } \\
\text { system and } \\
\text { warm water } \\
\text { layer }\end{array}$ & $\begin{array}{l}\text { - Warm Layer Heater } \\
\text { - Insulation valve } \\
\text { - Detector } \gamma \\
\text { (purification water) }\end{array}$ & $\begin{array}{l}\text { KBE02 AH-01 } \\
\text { KBE02 AA- } \\
\text { 01/AA-02 } \\
\text { KBE02 CR002 }\end{array}$ & $\begin{array}{c}15 \\
105 \\
22\end{array}$ & $\begin{array}{l}1 \\
3 \\
2\end{array}$ & $\begin{array}{l}1.4 \\
4.2 \\
2.8\end{array}$ \\
\hline $\begin{array}{l}\text { Sewer heat } \\
\text { dissipation } \\
\text { system }\end{array}$ & $\begin{array}{l}\text { - Circulating and } \\
\text { piping pumps in } \\
\text { pool cooling } \\
\text { systems } \\
\text { - Expansionary tubes } \\
\text { - Valves } \\
\text { - Heat exchanger }\end{array}$ & $\begin{array}{l}\text { JNA10/20/30 } \\
\text { AP001, } \\
\text { JNA10/20/30 } \\
\text { BR00 } \\
\text { JNA10/20/30 } \\
\text { BB001 } \\
\text { JNA10/20/30 } \\
\text { AA001 } \\
\text { JNA10/20/30 } \\
\text { BC001 }\end{array}$ & $\begin{array}{l}11 \\
28 \\
59\end{array}$ & $\begin{array}{l}2 \\
1 \\
6\end{array}$ & $\begin{array}{l}2.8 \\
1.4 \\
8.5\end{array}$ \\
\hline
\end{tabular}

From the duration maintenance analysis of SSC RSG-GAS (2010-2015) howed in Table 1, for cooling systems, purification systems and heat dissolution systems the highest results if sorted by 6 are: 1) Activity measurement instrumentation $\gamma$ continuously on secondary cooling system (PA01-02/CR001), 2) Primary purification pump (KBE01 AP-01-02), 3) cooling system for primary pumps on component JE-01 (AP01-02), 4) isolation valve Purification system and warm water layer (KBE02 AA-01/AA-02), subsequently followed by 5) Valves in the press pipe and backflow pipe on the secondary cooling system (PA01-02/ AA-14 and PA01-02/ AA 16) dan 6) Secondary System Instrumentation Flow ( PA01-02/CF002).

The maintenance data of the Cooling system and related systems of RSG-GAS Structure System and Component (SSC) for critical equipment identification (2010-2015) are shown in Table 2.

\section{Critical Equipment of SSC of the RSG GAS (2010-2015)}

Determination of Maintenance Priority Index (MPI) is done by calculating System Criticality Ranking (SCR) which consists of various aspects, namely: system, safety, quality and operational cost. Next is calculated Operation Criticality Ranking (OCR). The next stage is to determine the assessment of the impact of Asset Failure Probability Factor (AFPF). 
Table 2 Maintenance Data On Cooling Systems and Related Systems from

SSC of The RSG-GAS For Identification of Critical Eqiepment (2010-2015)

\begin{tabular}{|c|c|c|c|c|c|}
\hline Subsystem & Code & $\begin{array}{l}\text { Safety } \\
\text { Class }\end{array}$ & $\begin{array}{l}\text { Quality } \\
\text { Class }\end{array}$ & $\begin{array}{c}\text { System Aspect } \\
\text { (day) }\end{array}$ & $\begin{array}{c}\text { Maintenance costs } \\
\text { (in rupiah) }\end{array}$ \\
\hline \multirow{3}{*}{$\begin{array}{l}\text { Primary } \\
\text { Cooling } \\
\text { System }\end{array}$} & JE01(AP01-02) & $\mathrm{B}$ & 2 & 12 & 166.640 \\
\hline & JAA01 (CL001) & $\mathrm{B}$ & 3 & 9 & 0 \\
\hline & $\begin{array}{l}\text { SPR (JE-01 } \\
\text { CT811/821/831) }\end{array}$ & A & 2 & 6 & 0 \\
\hline \multirow{6}{*}{$\begin{array}{l}\text { Secondary } \\
\text { Cooling } \\
\text { System }\end{array}$} & PA-03 AP-01 & $\mathrm{C}$ & 3 & 4 & 86.350 \\
\hline & $\begin{array}{l}\text { PA01-02/ AA-14 and } \\
\text { PA01-02/ AA } 16\end{array}$ & $\mathrm{C}$ & 2 & 9 & 8.775 \\
\hline & PA-01-02-03/AA-03 & $\mathrm{C}$ & 3 & 11 & 3.750 \\
\hline & PA-01 CQ001 & $\mathrm{C}$ & 3 & 14 & 31.200 \\
\hline & PA01-02/CF002 & $\mathrm{C}$ & 3 & 13 & 0 \\
\hline & PA01-02/CR001 & $\mathrm{B}$ & 3 & 13 & 3.745 \\
\hline Primary & KBE01 AP-01-02 & $\mathrm{B}$ & 2 & 16 & 32.400 \\
\hline Purification & KBE01 CR001 & $\mathrm{B}$ & 2 & 10 & 0 \\
\hline System & KBE01 AA-67/ AA-68 & $\mathrm{A}$ & 1 & 5 & 1.260 \\
\hline Purification & KBE02 AH-01 & $\mathrm{B}$ & 2 & 15 & 5.850 \\
\hline system and & KBE02 AA-01/AA-02 & $\mathrm{A}$ & 1 & 35 & 1.200 \\
\hline $\begin{array}{l}\text { warm water } \\
\text { layer }\end{array}$ & KBE02 CR002 & $\mathrm{C}$ & 2 & 11 & 0 \\
\hline \multirow{4}{*}{$\begin{array}{l}\text { Sewer heat } \\
\text { dissipation } \\
\text { system }\end{array}$} & $\begin{array}{l}\text { JNA10/20/30 AP001, } \\
\text { JNA10/20/30 BR00 }\end{array}$ & A & 1 & 15 & 22.200 \\
\hline & JNA10/20/30 BB001 & $\mathrm{A}$ & 1 & 6 & 14.829 \\
\hline & JNA10/20/30 AA001 & $\mathrm{B}$ & 1 & 28 & 22.770 \\
\hline & JNA10/20/30 BC001 & A & 1 & 10 & 18.600 \\
\hline
\end{tabular}

\section{System Criticality Ranking (SCR)}

System Aspect: (Process Throughput) is the impact of loss of function or time range of improvement. The system aspect ranking is shown in Table 3.

Table 3. Aspects of the system

\begin{tabular}{lc}
\hline \multicolumn{1}{c}{ System } & Value \\
\hline No effect on the system & 1 \\
Take effect $1-7$ days & 2 \\
Take effect $>7-15$ days & 3 \\
Take effect $>15-30$ days & 4 \\
Take effect $>30$ days & 5 \\
\hline
\end{tabular}

\section{Safety Aspects}

The classification of systems/components in the RSG-GAS installation is based on safety aspects of grade A, B and C. The ranking for safety aspects is shown in Table 4.

Table 4. Safety Aspects

\begin{tabular}{lcc}
\hline \multicolumn{1}{c}{ Safety } & Grade & Value \\
\hline Directly affect safety & $\mathrm{A}$ & 3 \\
Indirectly affect safety & $\mathrm{B}$ & 2 \\
No effect on safety & $\mathrm{C}$ & 1 \\
\hline
\end{tabular}




\section{Quality Aspects}

The classification of equipment/components of quality is based on the accuracy or tolerance provided by the manufacturer. The ranking for quality aspects is shown in Table 5 .

Table 5. Quality Aspects

\begin{tabular}{lc}
\hline \multicolumn{1}{c}{ Quality Aspects } & Value \\
\hline Class 1: & 3 \\
equipment/component with tolerance $0 \mathrm{~s} / \mathrm{d} 5 \%$ & 2 \\
Class 2: & 1 \\
equipment/component with tolerance $>5 \mathrm{~s} / \mathrm{d} 10 \%$ & \\
$\begin{array}{l}\text { Class 3: } \\
\text { equipment/component with tolerance }>10 \%\end{array}$ \\
\hline
\end{tabular}

\section{Cost Aspects (Operational Cost)}

Operational cost is an average maintenance cost during the year of 2010-2015. The rankings for the operational costs are shown in Table 6.

Tabel 6. Operational Cost

\begin{tabular}{lc}
\hline \multicolumn{1}{c}{ Cost (in million rupiah) } & Value \\
\hline$<1$ & 1 \\
$\geq 1 \mathrm{~s} / \mathrm{d} 10$ & 2 \\
$>10 \mathrm{~s} / \mathrm{d} 50$ & 3 \\
$>50 \mathrm{~s} / \mathrm{d} 100$ & 4 \\
$>100 \mathrm{~s} / \mathrm{d} 200$ & 5 \\
\hline
\end{tabular}

\section{Operation Criticality Ranking (OCR):}

Operation Criticality Ranking is obtained based on the duration of the failure of the asset. The ranking for operational criticality is shown in Table 7 .

Table 7 Duration of Failure Time

\begin{tabular}{lc}
\hline Duration of Time Failure (days) & Value \\
\hline $1-10$ & 1 \\
$\geq 10 \mathrm{~s} / \mathrm{d} 20$ & 2 \\
$>20 \mathrm{~s} / \mathrm{d} 40$ & 3 \\
$>40 \mathrm{~s} / \mathrm{d} 60$ & 4 \\
$>60 \mathrm{~s} / \mathrm{d} 80$ & 5 \\
$>80 \mathrm{~s} / \mathrm{d} 100$ & 6 \\
$>100 \mathrm{~s} / \mathrm{d} 120$ & 7 \\
$>120 \mathrm{~s} / \mathrm{d} 140$ & 8 \\
$>140 \mathrm{~s} / \mathrm{d} 160$ & 9 \\
$>160 \mathrm{~s} / \mathrm{d} 180$ & 10 \\
\hline
\end{tabular}

\section{Asset Failure Probability Factor}

Asset Failure Probability Factor (AFPF) value is obtained by looking at the reliability level of equipment with parameters measured as damage from system / component in the period of 20102015. The AFPF value is the percentage of the frequency of interference (\%) for the whole system: the cooling system, the purification system and the decay heat dissipation system. The AFF ranking is shown in Table 8 . 
Table 8. Disturbance Fraction

\begin{tabular}{cc}
\hline Disturbance Fraction $(\%)$ & Value \\
\hline 0,1 & 1 \\
$>0,1-1$ & 2 \\
$>1-10$ & 3 \\
$>10-50$ & 4 \\
$>50-100$ & 5 \\
\hline
\end{tabular}

Based on Tables 3-8, it can be made of system aspect index, safety, quality aspects and cost. The value of the four aspects is shown in Figure 3. It can then be calculated the value of ACR, OCR, SCR, AFPF and MPI values. The values are shown in Table 9. The result of maintenance priority index (MPI) for components in the primary, secondary, purification and decay heat disposal systems after ranking is shown in Figure 4.

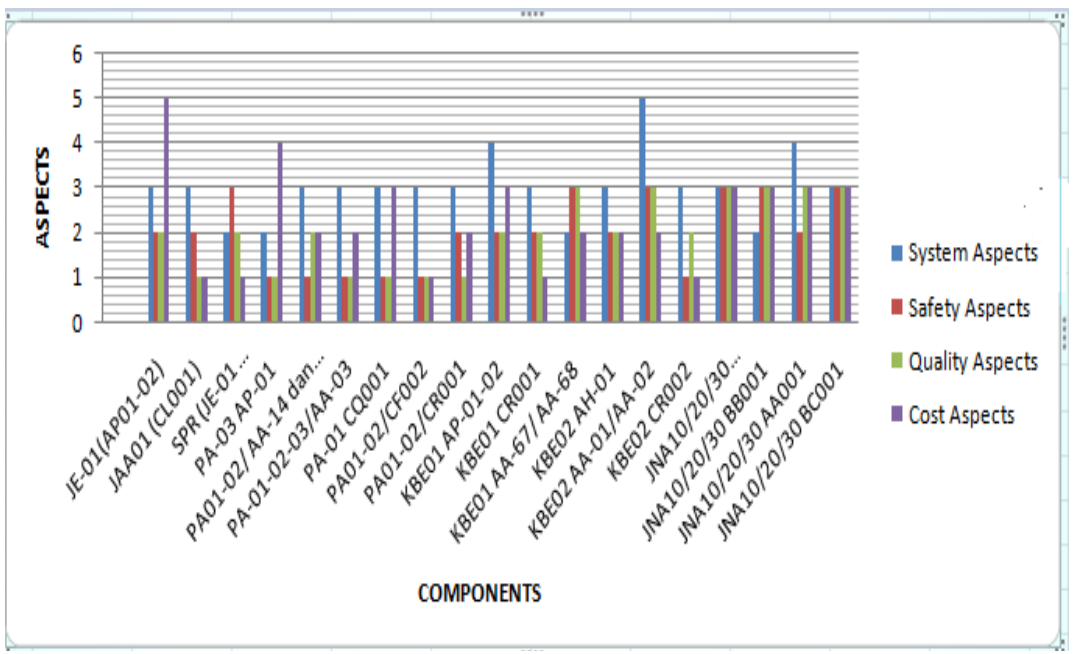

Figure 3. System Aspect Values

Table 9. Value ACR, OCR, SCR, AFF and MPI

\begin{tabular}{|c|c|c|c|c|c|}
\hline 1 & $A$ & B & c & D & E \\
\hline 1. & SCR & OCK & ACR & AFPF & MPI \\
\hline \multicolumn{6}{|l|}{2} \\
\hline 3 & 3.24 & 7 & 22.68 & 4 & 90.72 \\
\hline 4 & 1.936 & 2 & 3.872 & 3 & 11.616 \\
\hline 5 & 2.121 & 1 & 2.121 & 3 & 6.363 \\
\hline 6 & 2.345 & 1 & 2.345 & 3 & 7.035 \\
\hline 7 & 2.121 & 4 & 8.484 & 3 & 25.452 \\
\hline 8 & 1.936 & 2 & 3.872 & 3 & 11.616 \\
\hline 9 & 2.236 & 2 & 4.472 & 3 & 13.416 \\
\hline 10 & 1.732 & 4 & 6.928 & 3 & 20.784 \\
\hline 11 & 2.549 & 10 & 25.49 & 4 & 101.96 \\
\hline 12 & 2.872 & 10 & 28.72 & 5 & 143.6 \\
\hline 13 & 2.121 & 2 & 4.242 & 4 & 16.968 \\
\hline 14 & 2.549 & 3 & 7.647 & 4 & 30.588 \\
\hline 15 & 2.291 & 2 & 4.582 & 4 & 18.328 \\
\hline 16 & 3.428 & 7 & 23.996 & 4 & 95.984 \\
\hline 17 & 1.936 & 3 & 5.808 & 4 & 23.232 \\
\hline 18 & 3 & 2 & 6 & 3 & 18 \\
\hline 19 & 2.784 & 2 & 5.568 & 4 & 22.272 \\
\hline 20 & 3.082 & 3 & 9.246 & 3 & 27.738 \\
\hline 21 & 3 & 4 & 12 & 5 & 60 \\
\hline
\end{tabular}




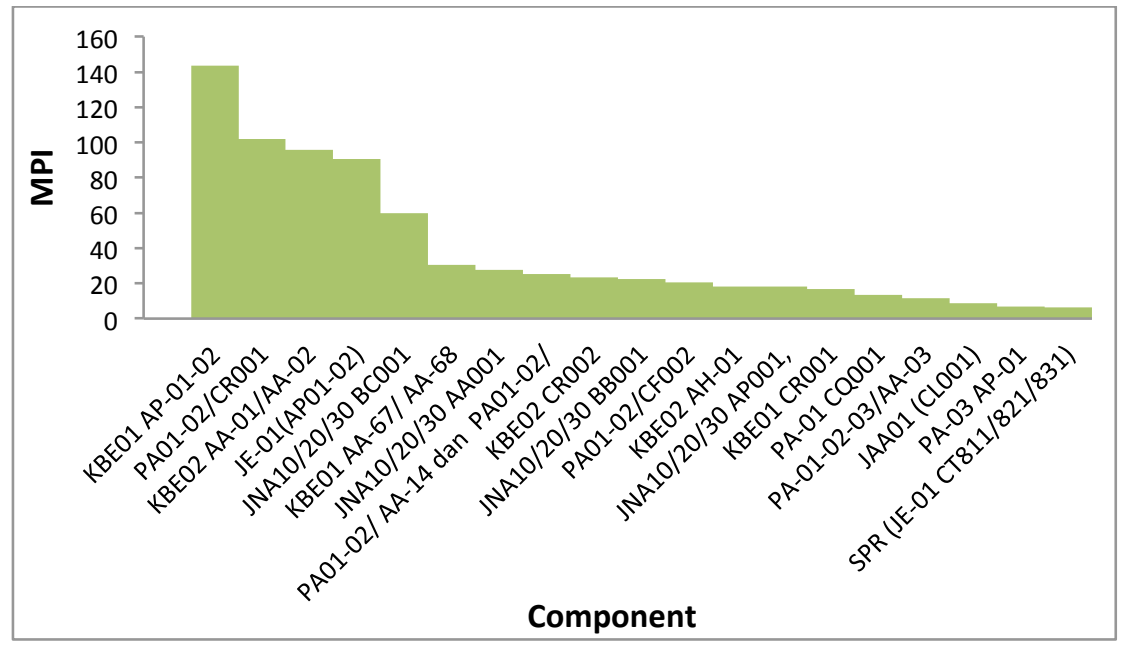

Figure 4. MPI Value for RSG-GAS Component

The MPI value for the top 5 if sorted is: KBE01 AP-01-02, PA01-02/CR001, KBE02 AA01/AA-02, JE-01(AP01-02) and JNA10/20/30 BC001 with MPI value 143, 101, 95,90 and 60. Maintenance management should prioritize or improve or add a peventative maintenance system to these five components.

If the MPI value we classify with 4 categories use clustering analysis $[12,13]$, then from Table 10 can be made categories such as Table 10. MPI value is very high for the components: KBE01 AP-01-02, PA01-02/CR001 and high category for components KBE02 AA-01/AA-02, JE-01(AP01-02) and JNA10/20/30 BC001.

Table 10. Category MPI Value

\begin{tabular}{lll}
\hline \multicolumn{1}{c}{ Category } & MPI Value & \multicolumn{1}{c}{ Components } \\
& $>100$ & KBE01 AP-01-02 and PA01-02/CR001 \\
\hline Very high & & \\
& & \\
High & & KBE02 AA-01/AA-02, JE-01(AP01-02) and \\
& & JNA10/20/30 BC001 \\
Medium & $>20-50$ & KBE01 AA-67/ AA-68, JNA10/20/30 AA001 \\
& & PA01-02/ AA-14 / AA 16, KBE02 CR002, \\
& & JNA10/20/30 BB001 and PA01-02/CF002 \\
Low & & KBE01CR001, KBE02 AH-01, \\
& & JNA10/20/30 AP001-JNA10/20/30 BR00, \\
& & PA-01 CQ001, JAA01 (CL001), PA-01-02-03/AA- \\
& & 03,PA-03 AP-01 and SPR (JE-01 CT811/821/831) \\
\hline
\end{tabular}

\section{CONCLUSION}

Each equipment (system/component) has a different level of criticality to the reliability of the system. The criticality level of each equipment determines its impact on the operating system and the direction of maintenance improvement. From SSC RSG-GAS downtime analysis (2010-2015) for cooling systems, purification systems and heat dissolution systems, the highest results if sorted by 6 are: 1) instrumentation of activity measurement $\gamma$ continuously on secondary cooling system (PA01-02/CR001), 2) Primary purification pump (KBE01 AP-01-02), 3) cooling system for the primary pump on the component JE-01(AP01-02), 4) isolation valves on purification systems and warm water layers (KBE02 AA-01/AA-02) further 5) Valves in the press pipe and backflow pipe on the secondary cooling system (PA01-02/ AA-14, PA01-02/ AA 16) and 6) Secondary System Instrumentation Flow ( PA01-02/CF002). Maintenance priority index of SSK RSG GAS for the top 5 if sorted are KBE01 AP-01-02, PA01-02/CR001, KBE02 AA-01/AA-02, JE-01(AP01-02) and 
JNA10/20/30 BC001. Very high MPI values for components: Primary purification pump (KBE01 AP-01-02) and continuous activity measurement instrumentation $\gamma$ (PA01-02/CR001) and high category for isolation valve components (KBE02 AA-01/AA-02) in the purification system and the warm water layer, the primary pump components (JE-01(AP01-02)) on the primary cooling system and heat exchanger components (JNA10/20/30 BC001) in the decay heat disposal system. Maintenance management should prioritize or improve preventative maintenance on these five components to reduce component criticality and enhanced system/component reliability.

\section{ACKNOWLEDGEMENT}

Author would like to thank Dr. R. M.Subekti, Dr. Syaiful Bakhri and Dr. Roziq Himawan, M.Eng who had given to advice and guidance during this research project. The research has been funded by BATAN DIPA 2017.

\section{REFERENCES}

1. International Atomic Energy Agency Ageing Management for Research Reactors. VIENNA: 2010.

2. Deswandri, Subekti M., Sunaryo G.R. Reliability Analysis of RSG-GAS Primary Cooling System to Support Aging Management Program Reliability Analysis of RSG-GAS Primary Cooling System to Support Aging Management Program. J. Phys. Conf. Ser. 2018. 962:116.

3. Andriulo S., Arleo M.A., Carlo F. De, Gnoni M.G., Tucci M., Andriulo S., et al. Effectiveness of of maintenance approaches for for High High Reliability Reliability Organizations Organizations Effectiveness of Reliability Organizations Effectiveness Reliability Organizations. IFAC-PapersOnLine. 2015. 48(3):466-71.

4. Saleh N., Sharawi A.A., Elwahed M.A., Petti A., Puppato D., Balestra G. Preventive Maintenance Prioritization Index of Medical Equipment Using Quality Function Deployment. 2015. 19(3):1029-35.

5. Heo J., Kim M., Kim D., Lyu J., Kang Y., Park J. Maintenance Priority Index of Overhead Transmission Lines for Reliability Centered Approach. 2014. 9(3)

6. Tang Y., Liu Q., Jing J., Yang Y., Zou Z. A framework for identi fi cation of maintenance signi fi cant items in reliability centered maintenance. 2017. 118

7. Keizer M.C.A.O., Teunter R.H., Veldman J. Joint condition-based maintenance and inventory optimization for systems with multiple components. 2017. 257:209-22.

8. Economics I.J.P., Mabrouk A. Ben, Chelbi A., Radhoui M. Optimal imperfect maintenance strategy for leased equipment. Intern. J. Prod. Econ. 2016. 178:57-64.

9. Florian M., Dalsgaard J. Planning of operation \& maintenance using risk and reliability based methods.Elsevier B.V.; 2015.

10. Dao C.D., Zuo M.J. Selective maintenance of multi-state systems with structural dependence. Reliab. Eng. Syst. Saf. 2017. 159(October 2015):184-95.

11. Verbert K., Schutter B. De, Babu R. Timely condition-based maintenance planning for multi-component systems. 2017. 159(August 2016):310-21.

12. Hartini E. Implementation of Missing Values Handling Method for Evaluating the System/Component Maintenance Historical Data. 2017. 19(1):11-8.

13. Hameed Z., Wang K. Clustering Analysis to Improve the Reliability and Maintainability of Wind Turbines with Self-Organizing Map Neural Network. 2013. 9(3):245-60. 